\title{
UNA DECISIÓN SOÑADA
}

\author{
Diana Ximena Santos* \\ Licenciada en Español e Inglés \\ Docente del Instituto Santa Teresita de Floridablanca, Santander \\ dianaxi_84@hotmail.com
}

El sueño podría no ser tan reparador como siempre se ha creído

El hombre despertó. Se detuvo con una expresión de odio en el labio inferior del rostro de la mujer y se marchó.

ÉL la había conocido tres años atrás. ELLA, muchacha joven, de tez morena, ojos saltones, labios gruesos y profundamente delineados, sin otra familia más que ELLA misma, no tuvo mucho que abandonar. ÉL, en cambio, se olvidó de todo, de su padre, madre y hermana menor. Esto sucedió, lo recuerdo bien, un caluroso mes de enero, luego de que ÉL no aguantará más su pasión por ELLA y decidiera escapar.

Con el poco dinero ahorrado en casa cuando aún era el niño de mamá, alquiló lejos de la ciudad un pequeño y modesto cuarto. Dispuso una litera que, doña Rosa, la dueña de la posada le ofreció y allí vivió desde aquel día, noches enteras de besos y caricias desenfrenadas. Sin otra alternativa, debió aprender a trabajar como ayudante de una construcción cercana a la posada. Salía muy temprano y regresaba siendo ya noche. ELLA era quien lo recibía con la cena, lo descalzaba, lo desvestía y le daba consoladores masajes con aceite de cocina usado. Después, de hablar sobre temas triviales que suelen penetrar los pensamientos de las parejas, hacían el amor. ÉL recorriendo y hundiendo su cuerpo en el de ELLA y ELLA ahogada de dicha en EL.

Pero llegó el momento en que para ÉL aquellos mimos, besos y abrazos de su mujer se

Diana Ximena Santos. Bucaramanga, diciembre 15 de 1984. Es Normalista Superior. Licenciada en Español y Literatura de la Universidad Industrial de Santander. En la actualidad es profesora del Instituto Santa Teresita y Coordinadora del área Lengua Castellana del mismo. convirtieron en mentira, en absurda falsedad. Como campana que avisa sobre el incendio, en el trabajo fue testigo involuntario de varios relatos escalofriantes sobre la indelidad femenina. Empezó a desconar. Nada más de escuchar esa palabra compuesta de cinco sílabas in-de-li-dad, el pensamiento se le nublaba, lanzaba improperios al mundo y a la primera mujer que había sido la condena para el hombre. Se le erizaba la piel, sentía miedo, no sabía qué hacer. Llevado por la lógica antes que por la razón, las dudas lo dominaron. Quiso conocer todo sobre su pasado. A diario, le preguntaba a doña Rosa por lo que ELLA hacía en el día y por lo que dejaba de hacer. Su vida se convirtió, en una tortuosa y constante indagación. Se la pasaba a la espera del día en que ELLA decidiera partir con otro hombre y abandonarlo.

ELLA por su parte, ajena a todo, seguía amándolo. A su temprana edad, veía su actitud como una etapa difícil de pareja que sólo con amor y paciencia podía ser superada. A pesar de sus esfuerzos por retomar y volver a los instantes de dicha, la situación empeoraba. Entre más tratara ELLA de comprenderlo, ÉL más se alejaba.

Una tarde, de regreso de la construcción, sin decir ni hacer gesto alguno a ELLA se extendió sobre la litera. Cayó de inmediato en un sueño profundo que ni ELLA pudo dañar al sollozar y al poner su cuerpecito delgado junto al suyo. Habrían transcurrido sólo unos pocos minutos, cuando ÉL despertó. Revisó con su mirada el cuarto entero. No vio a su mujer y corrió con desesperación. Preguntó a Doña Rosa por ELLA, recorrió fuera de la posada cuadras completas y 
por n ya cansado la encontró en una. Estaba allí, entre los brazos de un hombre al que no había visto jamás. El desconocido le rodeaba el cuerpo, mientras le mordía... ¡A ELLA!... ¡A su mujer!... el labio inferior que tanto goce le había ofrecido a ÉL en noches interminables de amor. Extenuado, retrocedió. Con la cabeza gacha y las piernas pesadas siguió calle abajo sin decir nada. 
